\title{
Processing of soot in an urban environment: case study from the Mexico City Metropolitan Area
}

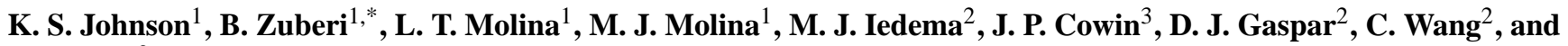 \\ A. Laskin ${ }^{2}$ \\ ${ }^{1}$ Department of Chemistry and of Earth, Atmospheric and Planetary Sciences, Massachusetts Institute of Technology, \\ Cambridge, MA, USA \\ ${ }^{2}$ William R. Wiley Environmental Molecular Sciences Laboratory, Pacific Northwest National Laboratory, Richland, WA, \\ USA \\ ${ }^{3}$ Chemical Science Division, Pacific Northwest National Laboratory, Richland, WA, USA \\ *now at: $\mathrm{GEO}_{2}$ Technologies, Woburn, MA, USA
}

Received: 27 May 2005 - Published in Atmos. Chem. Phys. Discuss.: 1 August 2005

Revised: 21 October 2005 - Accepted: 1 November 2005 - Published: 14 November 2005

\begin{abstract}
Chemical composition, size, and mixing state of atmospheric particles are critical in determining their effects on the environment. There is growing evidence that soot aerosols play a particularly important role in both climate and human health, but still relatively little is known of their physical and chemical nature. In addition, the atmospheric residence times and removal mechanisms for soot are neither well understood nor adequately represented in regional and global climate models. To investigate the effect of locality and residence time on properties of soot and mixing state in a polluted urban environment, particles of diameter 0.2-2.0 $\mu \mathrm{m}$ were collected in the Mexico City Metropolitan Area (MCMA) during the MCMA-2003 Field Campaign from various sites within the city. Individual particle analysis by different electron microscopy methods coupled with energy dispersed x-ray spectroscopy, and secondary ionization mass spectrometry show that freshly-emitted soot particles become rapidly processed in the MCMA. Whereas fresh particulate emissions from mixed-traffic are almost entirely carbonaceous, consisting of soot aggregates with liquid coatings suggestive of unburned lubricating oil and water, ambient soot particles which have been processed for less than a few hours are heavily internally mixed, primarily with ammonium sulfate. Single particle analysis suggests that this mixing occurs through several mechanisms that require further investigation. In light of previously published results, the internally-mixed nature of processed soot particles is expected to affect heterogeneous chemistry on the soot surface, including interaction with water during wet-removal.
\end{abstract}

Correspondence to: $\mathrm{K}$. S. Johnson

(kirstenj@mit.edu)

\section{Introduction}

Aerosols are important atmospheric constituents on local, regional and global scales. Exposure to particulate matter is correlated with increased human mortality (Dockery et al., 1993; Borja-Aburto et al., 1998; Pope et al., 2002; Evans et al., 2002), and particles influence the Earth's planetary albedo through direct and indirect climate effects (Penner et al., 2004; Sekiguchi et al., 2003; Loeb and Kato, 2002). Large variability in both aerosol emission sources and the chemical composition of individual particles introduces considerable uncertainty in assessing these effects (IPCC, 2001).

Soot particles warrant special attention because of their long-range transport (Ramamanthan et al., 2001; Rosen et al., 1981), complex role in climate (Ackerman et al., 2000), and large surface area that may facilitate heterogeneous reactions (Chughtai et al., 2002). Despite an immediate need to better quantify the lifetime of soot in the atmosphere, relatively little is currently understood regarding the processing of soot in the atmosphere, particularly in urban environments. An understanding of soot processing, including kinetics, is particularly important since the properties of soot particles may be significantly changed by their interaction with gaseous species such as $\mathrm{NO}_{\mathrm{y}}, \mathrm{O}_{3}, \mathrm{OH}$, and by mixing with other aerosols such as inorganic sulfates and nitrates.

Numerous studies have investigated heterogeneous reactions on a soot surface in a simulated polluted environment (e.g. Chughtai et al., 1993, 1994, 2003; Aubin et al., 2003; Ammann et al., 1998; Disselkamp et al., 2000; Kamm et al., 1999). Soot particles are largely composed of black carbon (BC) and are generally very hydrophobic, but they may become hydrophilic through physical and/or chemical changes that occur during atmospheric aging. Oxidation by

(C) 2005 Author(s). This work is licensed under a Creative Commons License. 
gaseous $\mathrm{NO}_{\mathrm{x}}, \mathrm{O}_{3}$, and $\mathrm{OH}$ has shown to lead to the formation of polar surface groups that can attract and retain water and therefore allow soot to become hydrophilic (Decesari et al., 2002; Chughtai et al., 1999; Zuberi et al., 2005). Soot particles may also become more hydrophilic through coalescence with, or condensation of, soluble inorganic or organic compounds such as sulfates, nitrates, and organic acids (Saathoff et al., 2003; Schnaiter et al., 2003; Kotzick et al., 1999). Estimates for the atmospheric lifetime of $\mathrm{BC}$ or soot depend on the hydrophobic to hydrophilic timescales that are assumed (Chung and Seinfeld, 2002; Reddy and Boucher, 2004; Koch, 2001; Cooke and Wilson, 1996; Barth and Church, 1995; Liousse et al., 1996). For example, a sensitivity analysis for BC hydrophilicity done by Cooke and Wilson showed a range of 6 to 10 days.

Soot and sulfate make up a substantial fraction of tropospheric aerosol in both urban and remote/rural areas and are known to become mixed (Barth and Church, 1995; Ramanathan et al., 2001; Clarke et al., 1997; Pósfai et al., 1999; Mallet et al., 2004; Hasegawa and Ohta, 2004). The nature of this mixing - external vs. internal - has been shown to dictate the radiative effects of mixed soot/sulfate particles (Fuller et al., 1999; Jacobson, 2001; Schnaiter et al., 2003; Lesins et al., 2002; Jacobson, 2000). Understanding the nature of mixed soot particles, including their physical, chemical and optical properties is essential in determining the role of soot in the atmosphere. Specifically, the extent to which processing causes soot particles to become hydrophilic is important in evaluating their susceptibility for washout, and hence their lifetimes. In this manuscript, we present the results of the microanalyses of individual particles collected in the Mexico City Metropolitan Area (MCMA) during the MCMA-2003 Field Campaign to illustrate the effects of atmospheric processing on freshly emitted soot particles.

\section{Experimental}

Methods of electron microscopy are effective and direct tools for studying composition and morphology of atmospheric particles. Scanning Electron Microscopy (SEM) and Transmission Electron Microscopy (TEM) with x-ray analysis provide detailed information on the nature of individual particles. Computer-Controlled Scanning Electron Microscopy with Energy Dispersed analysis of X-rays (CCSEM/EDX) has been developed in order to gain a wealth of information on thousands of particles by avoiding labor-intensive manual analysis (Cassucio et al., 1983; Schwoeble et al., 1984; Germani and Buseck, 1991). For single particle microscopy studies, the Time Resolved Aerosol Collector (TRAC) is a simple and efficient means of collecting and cataloguing atmospheric samples in a time-resolved fashion (Laskin et al., 2003). The TRAC is a conventional one stage jet-to-plate impactor, which deposits aerosols on filmed TEM grids prearranged on an impaction plate. The specially designed ar- rangement of the filmed grids in the impaction plate provides their tight contact with the plate surface.

Two newly designed, compact TRAC devices (Laskin et al., 2005a) were employed during MCMA-2003. The first TRAC was installed at the Centro Nacional de Investigación y Capacitación Ambiental (CENICA), the MCMA2003 Supersite located in the southeast MCMA. The second TRAC was placed on board the Aerodyne Mobile Laboratory (AML) during various in-city emissions characterization experiments. Collections at CENICA were made continuously during the campaign whereas the AML samples were collected at specific times and locations within the MCMA. Aerosol inlet flows for both TRAC instruments were maintained at approximately $0.8 \mathrm{~L} / \mathrm{min}$ with sampling intervals of 15 and $5 \mathrm{~min}$ for CENICA and AML, respectively. Particles were dried to $20 \%$ relative humidity at CENICA prior to collection. The sample substrates were $\mathrm{Cu} 400$ mesh TEM grids covered with thin Carbon Type-B films (Ted Pella, Inc., Redding, CA). During the run, each collection grid was continuously advanced in order to prevent collected particles from overlap. After the run, plates with the collected aerosol samples were sealed for storage. Particle samples were analyzed at the Environmental Molecular Sciences Laboratory (EMSL) located at Pacific Northwest National Laboratory (PNNL) immediately following the campaign. A FEI XL30 digital field emission gun Environmental Scanning Electron Microscope equipped with EDX microanalysis spectrometer (EDAX, Inc.) was used for CCSEM/EDX and SEM/EDX analysis. Specific details on the CCSEM/EDX analysis over particles collected on the filmed grids are published elsewhere (Laskin et al., 2001, 2003, 2005a). TEM studies utilized a high resolution JEOL JEF 2010F microscope operating at $200 \mathrm{keV}$. The images were recorded digitally with a slow scan chargecoupled device (CCD) camera. Time-of-Flight Secondary Ion Mass Spectrometry (TOF-SIMS) analysis was done with a Physical Electronics TRIFT II instrument utilizing an unbunched $25 \mathrm{kV} \mathrm{Ga}^{+}$primary ion beam. An area measuring $50 \mu \mathrm{m} \times 50 \mu \mathrm{m}$ was sputtered using a $60 \mathrm{pA}$ DC beam for $120 \mathrm{~s}$ (for a total dose of $2 \times 10^{15}$ ions $/ \mathrm{cm}^{2}$, or just enough to leave the static limit (Vickerman and Briggs, 2001) to remove slight polydimethylsiloxane (PDMS) contamination. A pulsed beam under otherwise identical conditions was used for analysis. The edges of the sputter crater are visible in the images, which allows definitive alignment of the negative and positive images.

\section{MCMA and particle sampling sites}

The MCMA consists of an urban area of $1500 \mathrm{~km}^{2}$ in a basin surrounded by mountains to the west, south and east. The complex terrain and meteorology, and their effects on the city's considerable air pollution problem have been the subject of many studies (e.g., Molina and Molina, 2002; 
Whiteman et al., 2000; Fast and Zhong, 1998; Raga et al., 1999). The MCMA houses a population of nearly 20 million residents and a fleet of 3.5 million vehicles including oldermodel taxis and microbuses ("colectivos") poorly equipped for emissions control. The transportation sector is a major source of particulate pollution, including soot (Molina and Molina, 2002).

In this study, three sampling sites were chosen to examine the evolution of traffic-emitted particulates in the urban environment of the MCMA:

1. Fresh city traffic particulate emissions. Vehicle exhaust plumes in the city center were directly sampled in order to capture freshly-emitted particles with minimal residence time prior to collection.

2. La Merced market area. La Merced is a large and congested market near downtown Mexico City selling a variety of food and household items. Major roads are within several hundred meters of the collection site. A small percentage of soot particles sampled at this site could be attributed to fresh emissions from vehicles passing near the collection device. However, the majority of particles collected near La Merced were most likely processed with less than a few hours residence time in the atmosphere.

3. CENICA site. CENICA is located in a mixed commercial-residential area with relatively few industries or congested road networks, and was thus assumed to be representative of ambient urban conditions. It is $8.8 \mathrm{~km}$ southeast from La Merced, and $2 \mathrm{~km}$ south from a large food market (Central de Abastos) that is frequented by delivery trucks, particularly in the early morning. An analysis of the meteorological patterns during the collection period shows that particles were transported to CENICA in air masses coming predominantly from the north (de Foy et al., 2005). In the absence of any major non-traffic soot source in the immediate neighborhood, soot particles collected at CENICA were assumed to be traffic related and to have originated primarily near the downtown area. Ambient particles were expected to have had the longest residence time of the three types of samples studied here, reflecting the maximum extent of particle processing in the urban environment.

Figure 1 shows the locations of La Merced and CENICA inside the MCMA.

\section{Results}

CCSEM/EDX, SEM and TEM analyses confirmed that soot and other carbonaceous particles were major components of MCMA aerosol concentration in the accumulation mode

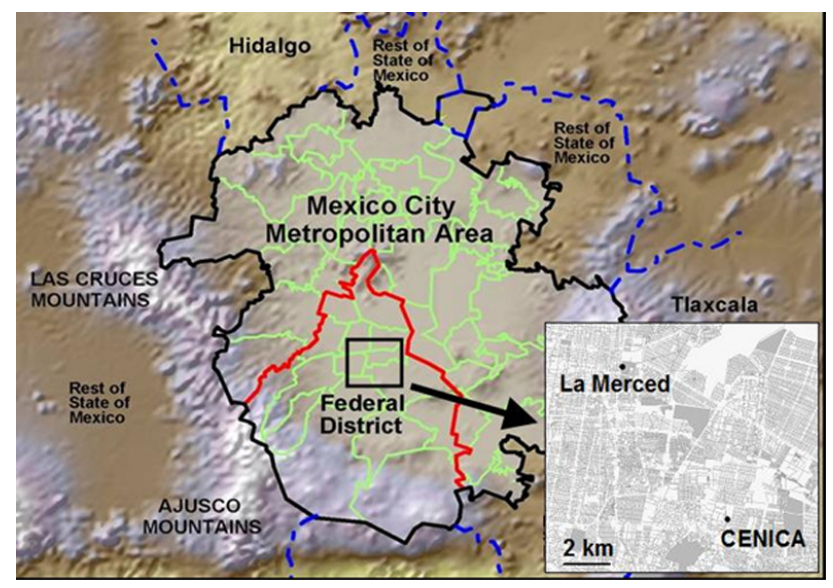

Fig. 1. Topographical map showing particle sampling locations in the MCMA. La Merced is located near downtown while CENICA is located to the southeast in a mixed commercial-residential area.

$(0.2-2.0 \mu \mathrm{m})$. However, the physical and chemical characteristics of the individual particles observed in the analyzed samples depended strongly upon their local environments.

\subsubsection{Fresh particulate emissions from downtown traffic}

The AML was equipped with gas inlets that allowed for mobile sampling from different locations within and surrounding the MCMA. In "chase mode", the AML followed a target vehicle to characterize its emissions in real time (Canagaratna et al., 2004). A video camera on board provided a visual record of the vehicles sampled, which for the discussion here consisted mostly of taxis and "colectivos". For these studies we did not attempt to investigate the particles emitted by individual vehicles, but instead sampled over a 5-min average to include a representative collection of traffic emissions.

Mixed-traffic particulate emissions consisted of soot aggregates coated with a liquid-like substance as shown by SEM in Fig. 2. This coating - apparent in the image as the darker gray substance surrounding the irregular soot aggregates - was most likely residue from unburned lubricating oil or fuel remaining on the emitted soot particles, and may have also included water soluble residues left on the substrate after drying in the vacuum chamber of the microscope. Sakurai et al. (2003) have shown that lubricating oil may comprise more than $95 \%$ of the volatile mass in diesel and gasoline emissions. Although this coating does not permit reporting an average particle diameter by CCSEM/EDX, closer inspection of the images reveals that mixed traffic emissions in the MCMA contained both submicron soot particles and larger aggregates $\geq 1 \mu \mathrm{m}$. This size range is consistent with studies of diesel particulate emissions by Kittelson et al. (2000).

More than 5000 individual particles were analyzed by CCSEM/EDX. In this study, we report changes in particle 

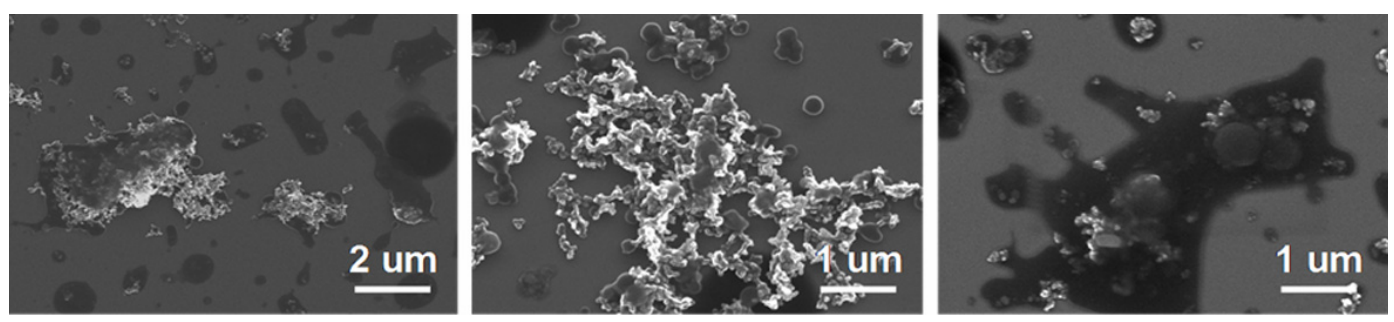

Fig. 2. SEM images of freshly-emitted soot particles collected in city traffic. The darker areas around the soot aggregates suggest a coating of unburned fuel or lubricating oil.
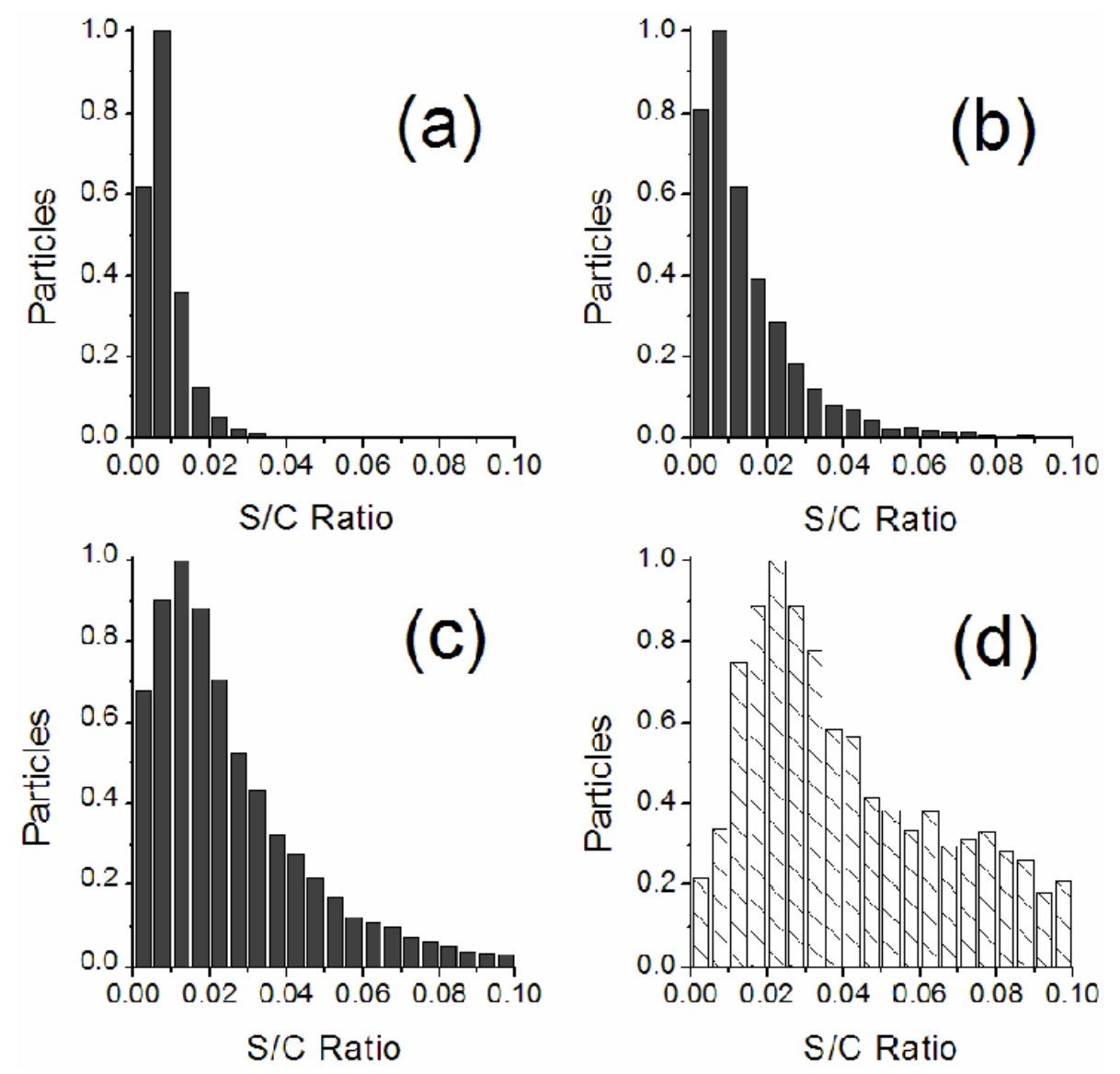

Fig. 3. Normalized distribution of S/C ratios from CCSEM/EDX analysis of MCMA samples and of laboratory-generated ammonium sulfate particles. S/C median values are (a) freshly-emitted soot from traffic $=0.007$, (b) La Merced (downtown) $=0.010$, (c) CENICA (ambient $)=0.020$, and $(\mathbf{d})$ ammonium sulfate $=0.045$.

elemental composition using relative ratios of element weight percent with respect to that of carbon $(\mathrm{S} / \mathrm{C}, \mathrm{O} / \mathrm{C}, \mathrm{N} / \mathrm{C}$, ex.). We note that carbon signal originates both from particle itself and the thin film carbon substrate. Nevertheless, this relative approach has been proven instrumental for distinguishing mixing characteristics of field collected particles including semi-quantitative analysis of low-Z elements $(\mathrm{C}$, N, O) (Cassucio et al., 2004; Hand et al., 2005; Pósfai et al., 2004; Laskin et al., 2002, 2005b).
Particulate traffic emissions in the MCMA were mostly carbonaceous with very low sulfur content. Figure 3a shows the narrow distribution and low median value of the EDX-determined S/C concentration ratio in these particles (Figs. 3b-d will be discussed in following sections). Since the very short residence time of fresh traffic particles leaves little opportunity for atmospheric processing, we believe that the sulfur detected in fresh soot particles most likely came directly from the fuel. During combustion, sulfur in gasoline 

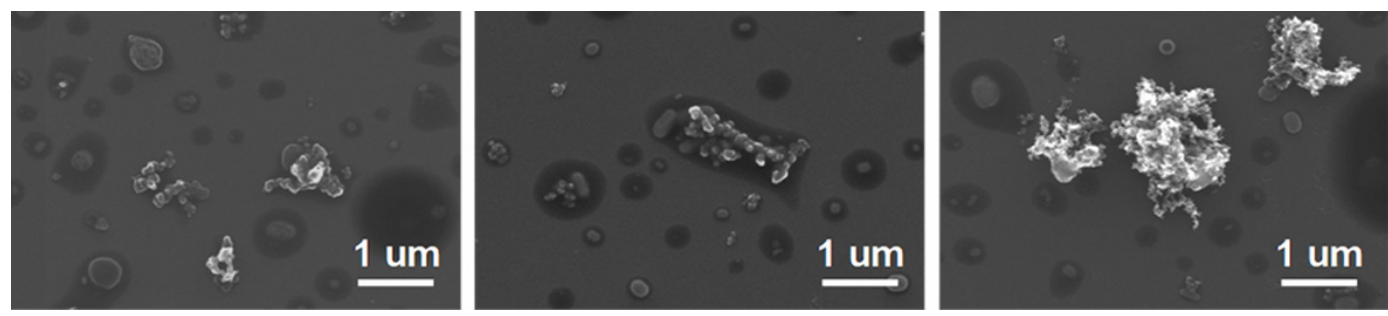

Fig. 4. SEM images of partially-processed soot particles sampled near the downtown La Merced site expected to contain a mix of fresh particulate emissions from passing vehicles as well as more-aged particles.
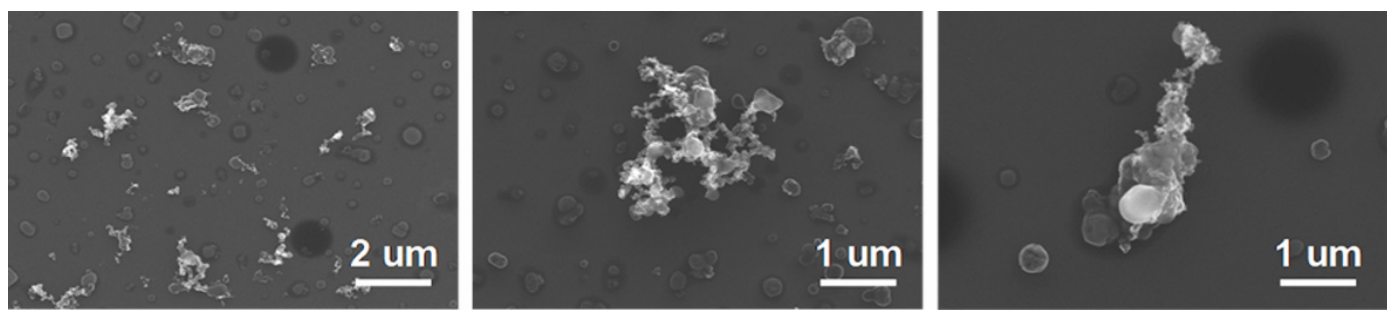

Fig. 5. SEM images of ambient particles collected at CENICA. Soot aggregates are heavily internally mixed with ammonium sulfate and other inorganic compounds.

or diesel fuel may be converted to sulfate in the presence of water vapor and condense on the soot particles (Shi and Harrison, 1999). Gasoline and diesel fuel at the time of this study reportedly contained a maximum of 500 to $1000 \mathrm{ppm}$ and average of 100 to $650 \mathrm{ppm}$ of sulfur depending on grade (PEMEX, 2003). This is only slightly higher than sulfur in the fuel used by Tobias et al. (2001) in studies of diesel particulate emissions where only few percent sulfuric acid was observed.

\subsubsection{Particles collected from the La Merced market area}

Particles collected near the La Merced market are visually and chemically distinguishable from freshly-emitted traffic particulates. As shown by SEM in Fig. 4, particles from the La Merced site exhibit both internal and external mixing. Soot particles in the samples have coagulated with or become entrained within other particulate matter. A small percentage of unmixed soot aggregates suggests influence of fresh emissions from traffic passing in close proximity to the sampling site. A liquid-like coating was once again observed on the particles and is visible in Fig. 4. However, the coating appeared to be less thick than observed on freshly-emitted soot particles, which may be a result of differences in particulate emissions according to vehicle type and its fuel efficiency. The majority of particles are submicron in size with an average diameter of $0.37 \pm 0.20 \mu \mathrm{m}$.

Nearly $75 \%$ of particles collected at La Merced contained sulfur; mixed particles also contained $\mathrm{Si}, \mathrm{K}, \mathrm{Fe}$ and $\mathrm{Na}$. Sulfate inclusions on soot aggregates were observed to readily decompose under the intensity of the electron beam as noted in previous microscopy studies (Ebert et al., 2002; Li et al., 2003). Figure $3 b$ illustrates the higher sulfur content of particles collected at La Merced and wider distribution of their $\mathrm{S} / \mathrm{C}$ ratios in comparison to the fresh particulate traffic emissions.

\subsubsection{Particles collected from the CENICA supersite}

SEM analysis reveals that processed soot particles in the MCMA were heavily internally mixed as shown in Fig. 5. Detailed morphological and composition analyses show that they were extremely heterogeneous and contained inclusions of $\mathrm{S}, \mathrm{K}$, and $\mathrm{Si}$, as well as $\mathrm{Fe}, \mathrm{Na}$ and $\mathrm{P}$ to a lesser extent. Figure 6 shows an example of SEM/EDX analysis of an individual soot particle. Inorganic components $\mathrm{Si}, \mathrm{K}$ and $\mathrm{S}$ most likely originated from different sources and emphasize extensive particle mixing. Compositional analysis of MCMA aerosol by Proton-Induced X-ray Emission (PIXE) at the CENICA site confirms S, Si and K as leading inorganic elements for particles $\leq 2.5 \mu \mathrm{m}$ (Johnson et al., 2005 ${ }^{1}$ ). Although the vacuum conditions necessary for SEM and TEM microscopy limit the detection of volatile organic, and a portion of nitrate and chloride compounds, the heavy internal mixing shown in Fig. 6 observed for the large majority of ambient particles strongly suggests that soot may be mixed with these compounds as well.

\footnotetext{
${ }^{1}$ Johnson, K. S., Molina, L. T., Molina, M. J., Shutthanandan, V., et al.: Composition and sourcing of aerosol in the Mexico City Metropolitan Area with PIXE/PESA/STIM and multivariate analysis, in preparation, 2005.
} 


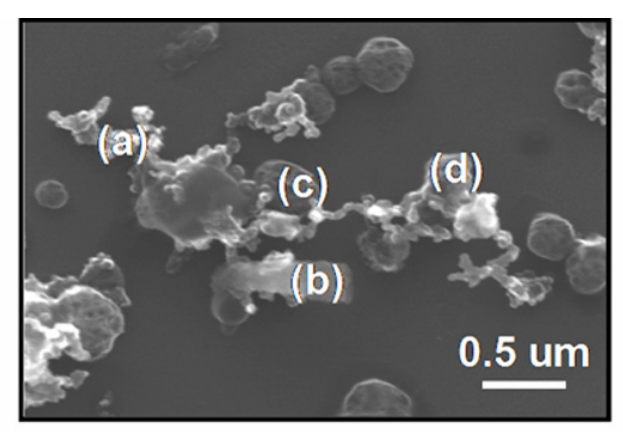

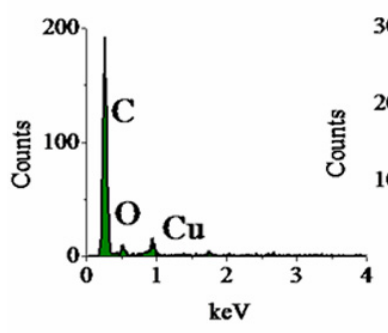

(a)

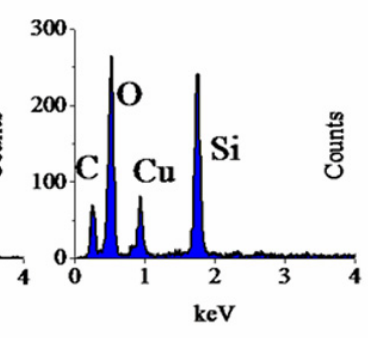

(b)

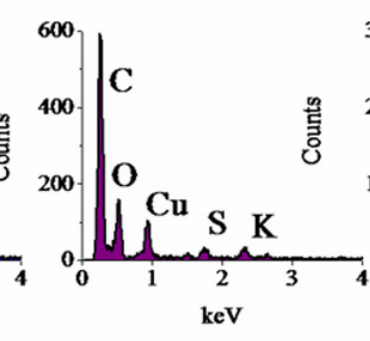

(c)

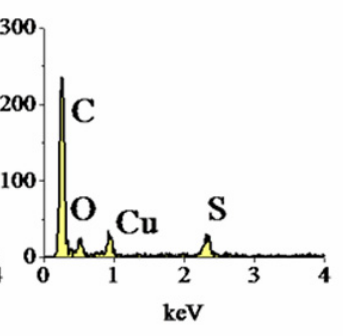

(d)

Fig. 6. SEM/EDX analysis showing the relative amount of the element indicated in a single processed soot particle collected at CENICA. The particle has become internally mixed with $\mathrm{S}, \mathrm{Si}$, and $\mathrm{K}$ during its residence time in the urban atmosphere. Cu is an artifact of the substrate grid.

Ambient particles had relatively high sulfur content as shown in Fig. 3c where their S/C ratios follow a much wider distribution than either freshly-emitted traffic particulates or particles collected near the La Merced market. CCSEM/EDX analysis of over 32000 particles from CENICA shows that nearly $90 \%$ contained sulfur and the average particle diameter was $0.39 \pm 0.19 \mu \mathrm{m}$.

Ammonia measurements, and Aerosol Mass Spectrometry (AMS) indicate that aerosols were fully neutralized during the majority of the campaign (Salcedo et al., 2005). To verify that sulfur was in the form of ammonium sulfate, TOF-SIMS analysis was done to make site-specific correlations among chemical ions in the particles. Overlapping $\mathrm{S}^{-}$ and $\mathrm{NH}_{4}^{+}$in Fig. 7 confirm the presence of ammonium sulfate. $\mathrm{Si}^{+}$and $\mathrm{Al}^{+}$indicate soil components, while $\mathrm{K}^{+}$and $\mathrm{Na}^{+}$suggest either biomass burning sources or salt from a dry lake bed (Moya et al., 2003). The overlap between ion pairs indicates that both components were found on the surface of the particles, which implies a degree of internal mixing. Laboratory-generated ammonium sulfate particles (average diameter $0.55 \pm 0.31 \mu \mathrm{m}$ ) were also analyzed by CCSEM/EDX following the same procedure as MCMA samples to compare typical $\mathrm{S} / \mathrm{C}$ values. The carbon signal detected by EDX in this sulfate control sample came only from the thin polymer substrate. Figure 3 shows that the S/C ratios of aerosol particles collected at the CENICA site (Fig. 3c) approach those measured for laboratory-generated ammonium sulfate particles (Fig. 3d), and support extensive processing of particles by ammonium sulfate.
While the CCSEM was used to provide data over large number of particles with statistical depth, Transmission Electron Microscopy (TEM) was performed to study the internal structure and composition of individual particles of specific interest. TEM images of Fig. 8 demonstrate two characteristic types of mixed soot/sulfate particles typical for the CENICA samples. In both images, soot, labeled (a), was unaffected by analysis whereas ammonium sulfate, labeled (b), rapidly decomposed under the intensity of the electron beam leaving behind sulfur residue. Whereas image (i) shows soot with a sulfate inclusion presumably from coagulation, image (ii) reveals soot spherules entirely embedded inside the remains of a sulfate particle and suggests condensation of sulfate on aged soot particles. The latter exemplifies the shell/core model discussed by Jacobson et al. (2000), among others, in determining the optical properties of mixed soot particles which has been used to evaluate black carbon specific absorption during MCMA-2003 (Barnard et al., 2005). This important distinction in soot/sulfate mixing suggests that multiple mechanisms occur in the MCMA, consistent with previous observations of structural and compositional variation in carbonaceous particles found in urban environments (Katrinak et al., 1992; Wentzel et al., 2003).

\subsection{Time resolution}

One of the distinct advantages of the TRAC-CCSEM/EDX approach is the ability to study aerosol composition as a function of time (Laskin et al., 2002, 2003, 2005b; Hand, 2005). 


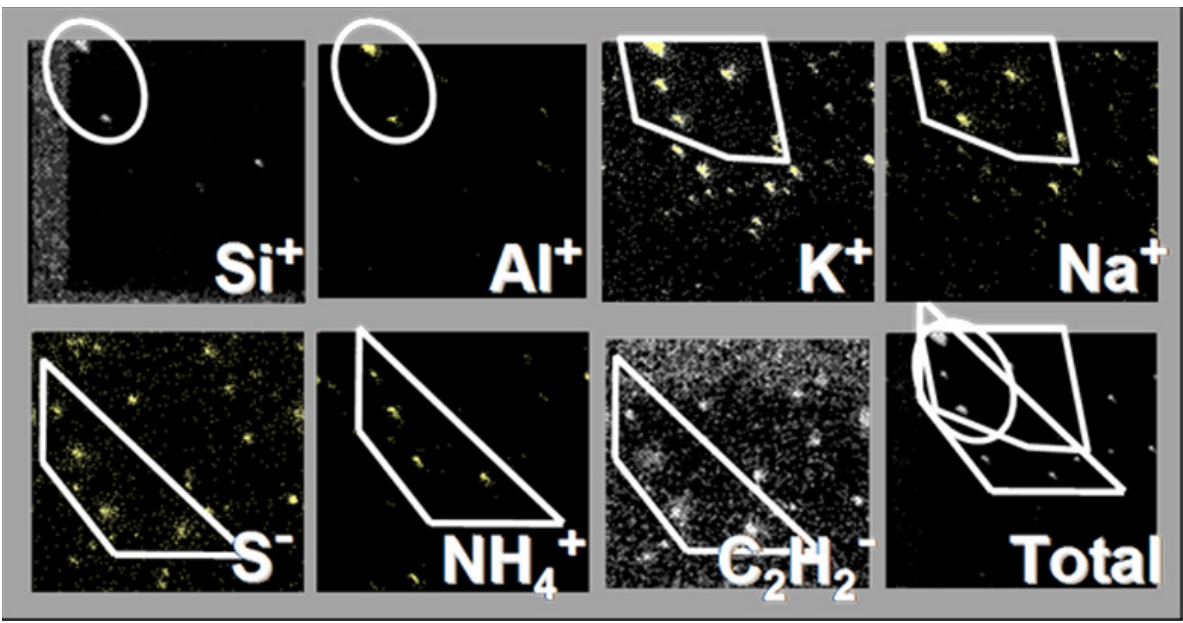

Fig. 7. TOF-SIMS analysis of a processed particle sample collected at CENICA. The single ion and composite images show the presence of the ion as bright signal against the dark background. Borders have been drawn to emphasize overlapping areas. $\mathrm{S}^{-}$and $\mathrm{NH}_{4}^{+}$ions indicate ammonium sulfate, $\mathrm{Si}^{+}$and $\mathrm{Al}^{+}$suggest soil, and $\mathrm{K}^{+}$and $\mathrm{Na}^{+}$may originate either from biomass burning or crustal salts. Each image is $50 \mu \mathrm{m} \times 50 \mu \mathrm{m}$.
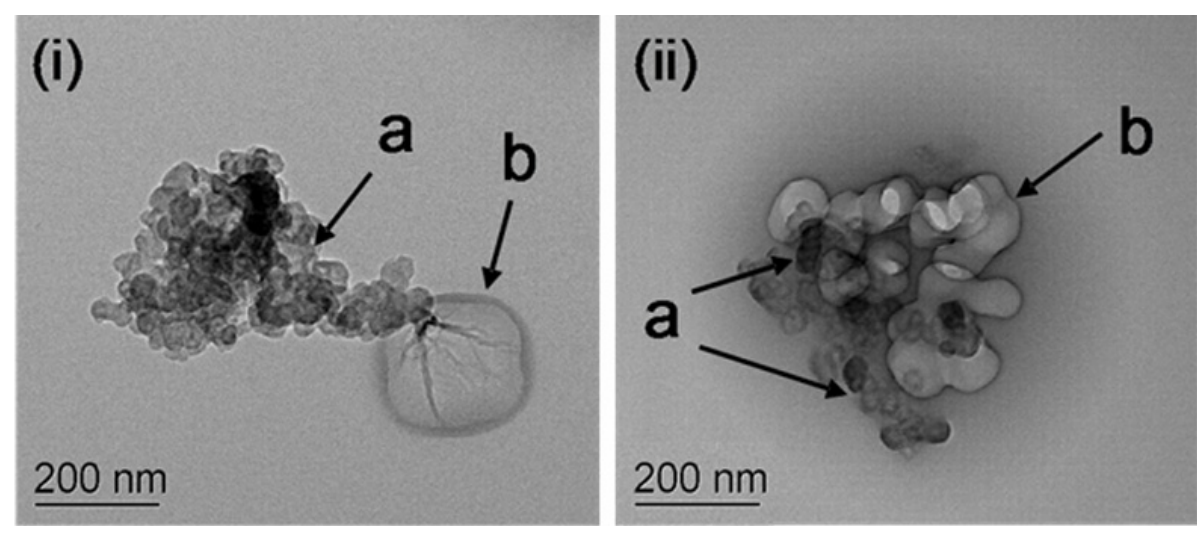

Fig. 8. TEM images of mixed soot/sulfate particles collected at CENICA. In both images, soot chains, (a) are internally-mixed with sulfate, (b) which is damaged by the electron beam leaving behind sulfur residue. Image (i) suggests coagulation whereas (ii) may indicate condensation of sulfate.

Figure 9 shows the median values of $\mathrm{S} / \mathrm{C}, \mathrm{O} / \mathrm{C}$ and N/C ratios from EDX analysis of individual ambient particles at CENICA over the course of one day, 22 April. The ratios track one another and provide further evidence for ammonium sulfate in the mixed aerosol, as well as relatively consistent and high sulfur content in the particles.

It is worth noting that a rain event occurred in the afternoon from approximately 03:30 to 04:30 p.m. A drop in S/C, $\mathrm{O} / \mathrm{C}$ and N/C ratios after the rain is consistent with preferential washout of particles with higher degree of mixing which would arguably make them more hydrophilic.

\section{Discussion}

As previously noted, the coating observed on both fresh soot and partially-processed soot is probably unburned lubricating oil remaining on the particles after their emission in vehicle exhaust and condensed water in the exhaust plume. The limitation of microscopic analysis techniques to measure volatile and semi-volatile compounds makes it difficult to determine the chemical makeup of the splashes surrounding the freshly-emitted soot particles. Although much of the organic particulate mass in vehicle emissions was assumed to have volatilized in the vacuum chamber prior to SEM/EDX analysis, the images of fresh soot particles suggest that a portion of the organics and/or water soluble residues was retained or otherwise left a footprint around the soot particles. Condensation of low vapor pressure organics would likely have 


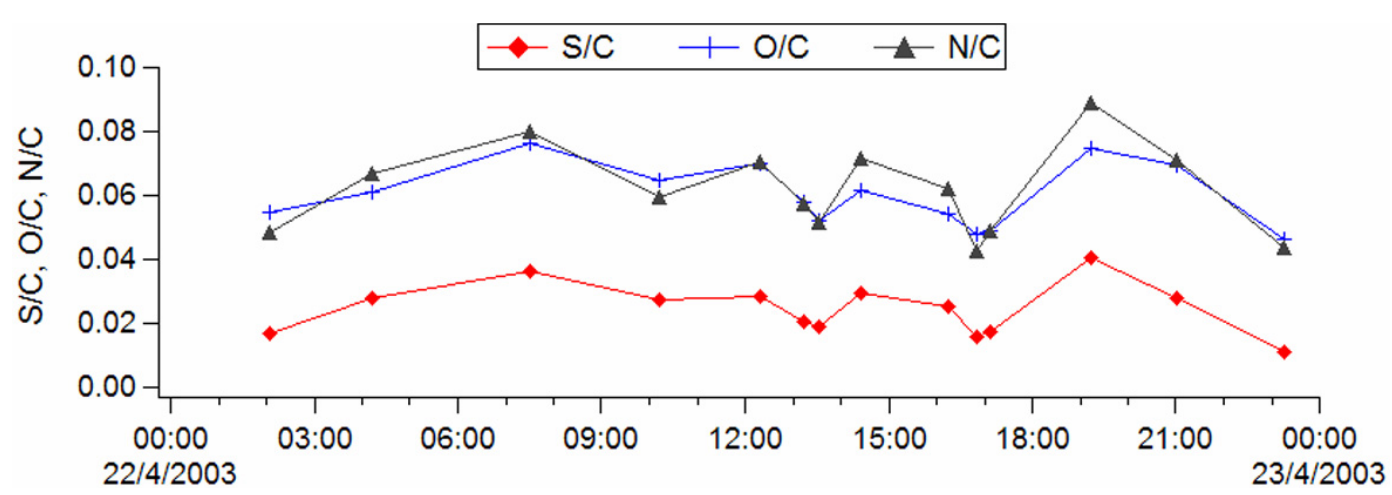

Fig. 9. Particle composition as a function of time as measured by CCSEM/EDX for particles collected on 22 April at CENICA. S/C, O/C and N/C track one another throughout the day as evidence for ammonium sulfate.

been possible, but because particles were sampled from a diverse fleet of vehicles, with and without catalytic converters, it would be impractical to discuss oxygenated organics with any certainty. Compositional studies done on diesel particulate emissions which found a signature of unburned lubricating oil appeared to provide the most logical explanation (Sakurai et al., 2003). Apparent differences in coating thickness may be related to the evaporation rate of condensed water from exhaust particles and to the effect of engine load on the volatile fraction of particulate emissions (Virtanen et al., 2004; Burtscher et al., 1998). The effect of an oil coating on the reactivity of soot, as well as the consequences on health have not been addressed and should be considered in future studies.

TEM has been used previously to investigate soot/sulfate mixing both in laboratory and field studies (Schnaiter et al., 2003; Ebert et al., 2002; Pósfai et al., 1999). The fact that we have observed sulfate either encapsulating a soot aggregate or as individual inclusions on soot suggests that multiple soot/sulfate mixing mechanisms occur in the MCMA. Two types of mixing shown by TEM analysis in Fig. 8 seem to provide evidence for both coagulation and condensation of sulfate on soot. These processes may occur on different time-scales depending on particle concentration and the rate of sulfate formation. For example, Riemer et al. (2004) have modeled aging of soot and calculated that condensation of sulfate (as sulfuric acid) dominates during the day whereas coagulation is favored at night, largely due to the daytime production of sulfate by $\mathrm{OH}$ oxidation of $\mathrm{SO}_{2}$.

In order to place our observations within context regarding particulate transport and residence time, it is important to note that MCMA pollutants are generally swept from the basin daily (Fast and Zhong, 1998; Whiteman, 2000). As such, extensive internal mixing of soot cannot be explained by multiple day accumulation that allows for gradual processing. The basin meteorology during MCMA-2003 has been studied in detail by de Foy et al. (2005), who classified days into various episodes with common circulation pat- terns. Most of our CENICA samples, including those featured in Fig. 3, were collected on "Cold Surge" days, when the winds came fairly consistently from the north/northwest at speeds between 1 and $4 \mathrm{~m} / \mathrm{s}$. The transport time for particles to reach CENICA from downtown areas such as La Merced would therefore range from little more than $30 \mathrm{~min}$ to several hours. If we assume that the majority of soot particles collected at CENICA originated from downtown traffic, consistent with the wind direction and large contribution of mobile sources to soot emissions in the MCMA, our results indicate that extensive soot processing occurs within hours. As an observation-based approximation, this should prompt more detailed laboratory studies of soot mixing times and the mechanisms involved.

The influence of environment on processing of particles and their mixing characteristics has been noted previously. Mallet et al. (2004) and Hasegawa and Ohta (2003) discuss the differences in mixing characteristics of aerosols in urban vs. rural locations, and have used their findings to suggest that urban aerosols tend to be externally mixed whereas aerosols in remote areas are more often internally mixed. They reason that aerosols in remote areas have a longer residence time, resulting in more extensive processing. Indeed, Pósfai et al. (1999) and Clarke et al. (1997) report internal mixing of soot/sulfate particles over the South Atlantic Ocean; Pósfai et al. (1999) have estimated that $11 \%$ to $46 \%$ of sulfate aerosols there contained a soot core. Our results show that a high degree of internal mixing of aerosols is possible even in urban environments such as the MCMA. The especially large vehicle fleet in Mexico City, high particulate emissions, and enclosed topography may help rationalize this intense particle mixing.

Internal mixing with sulfate is expected to affect the lifetime of soot in the atmosphere. Freshly-emitted soot particles are initially very hydrophobic, but may become more susceptible to removal by wet deposition once they have collected soluble components. Although the ability of soot particles to be washed out is not currently well characterized, 
measurements such as those by Ducret and Cachier (1992) and Sellegri et al. (2003) show substantial wet scavenging of aged carbon aerosols. Global climate models estimate a lifetime of soot of 4 to 10 days (Chung and Seinfeld, 2002; Reddy and Boucher, 2004; Koch, 2001; Cooke and Wilson, 1996; Barth and Church, 1995; Liousse et al., 1996) by making different assumptions on the time required for hydrophobic soot to become hydrophilic. For example, Chung and Seinfeld (2002) used an exponential hydrophobic soot lifetime of 1.15 days, while Cooke and Wilson (1996) assumed an arbitrary 5\% conversion per 2-h time step. The extensive soot processing we have observed in the MCMA suggests that the hydrophobic lifetime of soot particles in urban environments, and hence the particles' overall atmospheric lifetimes, may be overestimated. A shorter lifetime of soot would also impact its range of transport after emission in traffic and from other anthropogenic sources.

\section{Conclusions}

Atmospheric particles of diameter $0.2-2 \mu \mathrm{m}$ were sampled in the MCMA during the MCMA-2003 Field Campaign and analyzed for chemical composition, size, and morphology to investigate their chemical and physical characteristics. While soot particles collected in city traffic were mostly irregular aggregates with low sulfur content, ambient soot particles showed physical and chemical differences as the result of atmospheric processing. Our studies indicate that processing of soot by ammonium sulfate occurs rapidly in the MCMA leading to internally-mixed particles. By comparing the characteristics of freshly-emitted particles from traffic, partiallyprocessed particles collected near a busy market, and ambient particles from a residential site, we estimate that extensive processing occurs within a day. CCSEM/EDX analysis of ambient particle samples shows that $\mathrm{S} / \mathrm{C}, \mathrm{O} / \mathrm{C}$, and N/C ratios follow one another in time suggesting the presence of ammonium sulfate, which is also confirmed by TOF-SIMS analysis. TEM and SEM imaging with $\mathrm{x}$-ray analysis shows processed soot particles in the accumulation mode that have either inorganic inclusions or are entirely encased within sulfate particles. Additional studies are needed to clarify the mechanisms of soot/sulfate mixing, as well as the susceptibility of mixed particles for removal by wet deposition. The observation of an oil coating on fresh soot particles should be examined more closely both in terms of reactivity and consequences for human health.

Acknowledgements. We are grateful to Aerodyne Research, Inc. for their assistance with the vehicle emissions collections and to the researchers and staff of CENICA for hosting the MCMA-2003 campaign. A portion of this research was performed in the William R. Wiley Environmental Molecular Sciences Laboratory, a national scientific user facility sponsored by the Department of Energy's Office of Biological and Environmental Research and located at Pacific Northwest National Laboratory (PNNL). PNNL is operated by the US Department of Energy by Battelle Memorial Institute under contract No. DE-AC06- 76RL0 1830. The MIT team gratefully acknowledge financial support from the Comision Ambiental Metropolitana of Mexico and from the US National Science Foundation (Award ATM 308748). The PNNL research group acknowledges support provided from Laboratory Directed Research and Development funds of PNNL and the Atmospheric Science Program of the Office of Biological and Environmental Research (OBER), US Department of Energy (DOE). B. Zuberi wishes to thank $\mathrm{GEO}_{2}$ Technologies for their support.

Edited by: C. E. Kolb

\section{References}

Ackerman, A. S., Toon, O. B., Stevens, D. E., Heymsfield, A. J., Ramananthan, V., and Welton, E. J.: Reduction of tropical cloudiness by soot, Science, 288, 1042-1047, 2000.

Ammann, M., Kalberer, M., Jost, D. T., Tobler, L., Rossler, E., Piguet, D., Gaggeler, H. W., and Baltensperger, U.: Heterogeneous production of nitrous acid on soot in polluted air masses, Nature, 395, 157-160, 1998.

Aubin, D. G. and Abbatt, J. P.: Adsorption of gas-phase nitric acid to n-hexane soot: Thermodynamics and mechanism, J. Phys. Chem. A., 107, 11 030-11 037, 2003.

Barnard, J. C., Kassianov, E. I., Ackerman, T. P., Frey, S., Johnson, K., Zuberi, B., Molina, L. T., Molina, M. J., Gaffney, J. S., and Marley, N. A.: Measurements of Black Carbon Specific Absorption in the Mexico City Metropolitan Area during the MCMA 2003 Field Campaign, Atmos. Chem. Phys. Discuss., 5, 40834113, 2005,

SRef-ID: 1680-7375/acpd/2005-5-4083.

Barth, M. C. and Church, A. T.: Regional and global distributions and lifetimes of sulfate aerosols from Mexico City and southeast China, J. Geophys. Res., 104, 30 231-30 239, 1995.

Borja-Aburto, V. H., Castillejos, M., Gold, D. R., Bierzwinski, S., and Loomis, D.: Mortality and Ambient Fine Particles in Southwest Mexico City, 1993-1995, Environ. Health Perspect., 106, 849-855, 1998.

Burtscher, H., Kunzel, S., and Huglin, C.: Characterization of particles in combustion engine exhaust, J. Aerosol Sci., 29, 389-396, 1998.

Casuccio, G. S., Janocko, P. B., Lee, R. J., Kelly, J. F., Dattner, S. L., and Mgebroff, J. S.: The Use of Computer-Controlled Scanning Electron-Microscopy in Environmental-Studies, J. Air Poll. Control Assoc., 33, 937-943, 1983.

Casuccio, G. S., Schlaegle, S. F., Lersch, T. L., Huffman, G. P., Chen, Y. Z., and Shah, N: Measurement of fine particulate matter using electron microscopy techniques, Fuel Proc. Tech., 85(6-7), 763-779, 2004.

Canagaratna, M. R., Jayne, J. T., Ghertner, D. A., Herndon, S., Shi, Q., Jimenez, J. L., Silva, P. J., Williams, P., Lanni, T. Drewnick, F., Demerjian, K. L. Kolb, C. E., and Worsnop, D. R.: Chase studies of particulate emissions from in-use New York City vehicles, Aerosol Sci. Technol., 38, 555-573, 2004.

Chughtai, A. R., Brooks, M. E., and Smith, D. M.: Effect of metal oxides and black carbon (soot) on $\mathrm{SO}_{2} / \mathrm{O}_{2} / \mathrm{H}_{2} \mathrm{O}$ reaction systems, Aerosol Sci. Technol., 19, 121-132, 1993. 
Chughtai, A. R., Gordon, S. A., and Smith, D. M.: Kinetics of the hexane soot reaction with $\mathrm{NO}_{2} / \mathrm{N}_{2} \mathrm{O}_{4}$ at low concentration, Carbon, 32, 405-416, 1994.

Chughtai, A. R., Williams, G. R., Atteya, M. O., Miller, N. J., and Smith, D. M.: Carbonaceous particle hydration, Atmos. Environ., 33, 2679-2687, 1999.

Chughtai, A. R., Kim, J. M., and Smith, D. M.: The effect of air/fuel ration on properties and reactivity of combustion soots, J. Atmos. Chem., 43, 21-43, 2002.

Chughtai, A. R., Kim, J. M., and Smith, D. M.: The effect of temperature and humidity on the reaction of ozone with combustion soot: implications for reactivity near the tropopause, J. Atmos. Chem., 45, 231-243, 2003.

Chung, S. H. and Seinfeld, J. H.: Global distribution and climate forcing of carbonaceous aerosols, J. Geophys. Res., 107, D19, 4407, doi:10.1029/2001JD001397, 2002.

Clarke, A. D., Uehara, T., and Porter, J. N.: Atmospheric nuclei and related aerosol fields over the Atlantic: clean subsiding air and continental pollution during ASTEX, J. Geophys. Res., 102, 25 281-25 292, 1997.

Cooke, W. F. and Wilson, J. J. N.: A global black carbon aerosol model, J. Geophys. Res., D14, 19395-19409, 1996.

De Foy, B., Caetano, E., Magana, V., Zitácuaro, A., Cárdenas, B., Martínez, A. P., Retama, A., Ramos, R., Reyes, R., Sosa, G., Molina, L. T., and Molina, M. J.: Mexico City basin wind circulation during the MCMA-2003 field campaign, Atmos. Chem. Phys., 5, 2267-2288, 2005,

SRef-ID: 1680-7324/acp/2005-5-2267.

Decesari, S., Facchini, M. C., Matta, E., Mircea, M., Fuzzi, S., Chughtai, A. R., and Smith, D. M.: Water soluble organic compounds formed by oxidation of soot, Atmos. Environ., 36, 18271832, 2002.

Disselkamp, R. S., Carpenter, M. A., Cowin, J. P., Berkowitz, C. M., Chapman, E. G., Zaveri, R. A., and Laulainen, N. S.: Ozone loss in soot aerosols, J. Geophys. Res., 105, 9767-9771, 2000.

Dockery, D. W., Pope III, C. A., Xu, X., Spengler, J. D., Ware, J. H., Faye, M. E., Ferris, B. G., and Speizer, F. E.: An association between air pollution and mortality in six U.S. cities, N. Engl. J. Med., 329, 1753-1759, 1993.

Ducret, J. and Cachier, H.: Particulate carbon content in rain at various temperate and tropical locations, J. Atmos. Chem., 15, 55-67, 1992.

Ebert, M., Weinbruch, S., Rausch, A., Gorzawski, G., Hoffmann, P., Wex, H., and Helas, G.: Complex refractive index of aerosols during LACE 98 as derived from the analysis of individual particles, J. Geophys. Res., 107, D21, 8121, doi:10.1029/2000JD000195, 2002.

Evans, J., Levy, J., Hammitt, J., Burgoa, C. S., and Castillejos, M.: Health benefits of air pollution control, Chapter 4, in: Air Quality in the Mexico City Megacity Megacity: An Integrated Assessment, edited by: Molina, L. T. and Molina, M. J., Kluwer Academic Publishers, 2002.

Fast, J. D. and Zhong, S.: Meteorological factors associated with inhomogeneous ozone concentrations within the Mexico City basin, J. Geophys. Res., 103, 18 927-18 946, 1998.

Fuller, K. A., Malm, W. C., and Kreidenweis, S. M.: Effects of mixing on extinction by carbonaceous particles, J. Geophys. Res., 104, 15 941-15 954, 1999.

Germani, M. S. and Buseck, P. R.: Automated Scanning Electron-
Microscopy for Atmospheric Particle Analysis, Anal. Chem., 63, 2232-2237, 1991.

Grgić, I., Hudnik, V., and Bizjak, M.: Aqueous S(IV) oxidation III. Catalytic effect of soot particles, Atmos. Environ., 27, 14091416, 1993.

Hand, J. L., Malm, W. C., Laskin, A., Day, D., Lee, T., Wang, C., Carrico, C., Carrillo, J., Cowin, J. P., Collett Jr, J., and Iedema. M. J.: Optical, physical and chemical properties of tar balls observed during the Yosemite Aerosol Characterization Study, J. Geophys. Res., 110, D21210, doi:10.1029/2004JD005728, 2005.

Hasegawa, S. and Ohta, S.: Some measurements of the mixing state of soot-containing particles at urban and non-urban sites, Atmos. Environ., 36, 3899-3908, 2002.

Intergovernmental Panel on Climate Change 2001, Scientific Basis, 105 pp., Cambridge Univ. Pres, New York, 2001.

Jacobson, M. Z.: A physically-based treatment of elemental carbon optics: Implications for global direct forcing of aerosols, Geophys. Res. Lett., 27, 217-220, 2000.

Jacobson, M. Z.: Strong radiative heating due to the mixing state of black carbon in atmosphere aerosols, Nature, 409, 695-697, 2001.

Kamm, S., Möhler, O., Naumann, K. H., Saathoff, H., and Schurath, U.: The heterogeneous reaction of ozone with soot aerosol, Atmos. Environ., 33, 4651-4661, 1999.

Katrinak, K. A., Rez, P., and Buseck, P. R.: Structural variations in individual carbonaceous particles from an urban aerosol, Environ. Sci. Technol., 26, 1967-1976, 1992.

Kittelson, D., Johnson, J., Watts, W., Wei, Q., Drayton, M., Paulsen, D., and Bukowiecki, N.: Diesel aerosol sampling in the atmosphere, SAE Tech. Paper Ser. No. 2000-01-2212, 2000.

Koch, D.: Transport and direct radiative forcing of carbonaceous and sulfate aerosols in the GISS GCM, J. Geophys. Res., 106, 20311-20 332, 2001.

Kotzick, R. and Niessner, R.: The effects of the aging process on critical supersaturation ratios of ultrafine carbon aerosols, Atmos. Environ., 33, 2669-2677, 1999.

Laskin, A. and Cowin, J. P.: Automated single particle SEM/EDX analysis of submicrometer particles down to $0.1 \mu \mathrm{m}$, Anal. Chem., 73, 1023-1029, 2001.

Laskin, A., Iedema, M. J., and Cowin, J. P.: Quantitative timeresolved monitoring of nitrate formation in sea salt particles using a CCSEM/EDX single particle analysis, Environ. Sci. Tech., 36, 4948-4955, 2002.

Laskin, A., Iedema, M. J., and Cowin, J. P.: Time-resolved aerosol collector for CCSEM/EDX single-particle analysis, Aerosol Sci. Tech., 37, 246-260, 2003.

Laskin, A., Cowin, J. P., and Iedema, M. J.: Off-line analysis of individual environmental particles using modern methods of electron microscopy and X-ray microanalysis, J. Electron Spectr. and Rel. Phenom., in press, doi:10.1026/j.elspec.2005.06.008, 2005a.

Laskin, A., Iedema, M. J., Ichkovich, A., Graber, E. R., Taraniuk, I., and Rudich, Y.: Direct observation of completely processed calcium carbonate dust particles, Faraday Discuss., 453-468, 130, doi:10.1039/b41736j, 2005b.

Lesins, G., Chylek, P., and Lohmann, U.: A study of internal and external mixing scenarios and its effect on aerosol optical properties and direct radiative forcing, J. Geophys. Res., 107, D10, 4094, doi:10.1029/2001JD000973, 2002. 
Li, J., Anderson, J. R., and Buseck, P. R.: TEM study of aerosol particles from clean and polluted marine boundary layers over the North Atlantic, J. Geophys. Res., 108(D6), 4189, doi:10.1029/2002JD002106, 2003.

Liousse, C., Penner, J. E., Chuang, C., Walton, J. J., Eddleman, H., and Cachier, H: A global three-dimensional model study of carbonaceous aerosols, J. Geophys. Res., 101, 19411-19432, 1996.

Loeb, N. G. and Kato, S.: Top-of-atmosphere direct radiative effect of aerosols over the tropical oceans from the clouds and the earth's radiant energy system (CERES) satellite instrument, J. Climate, 15, 1474-1484, 2002.

Mallet, M., Roger, J. C., Depiau, S., Putaud, J. P., and Dubovik. O.: A study of the mixing state of black carbon in urban zone, J. Geophys. Res., 109, D0402, doi:10.1029/2003JD003940, 2004.

Molina, M. J. and Molina, L. T. (Eds.): Air Quality in the Mexico Megacity: An Integrated Assessment, Kluwer Academic, 2002.

Novakov, T., Chang, S. G., and Harker, A. B.: Sulfates as pollution particulates: Catalytic formation on carbon (soot) particles, Science, 186, 259-261, 1974.

PEMEX: Calidad de Combustibles, 2003.

Penner, J. E., Dong, X., and Chen, Y.: Observational evidence of a change in radiative forcing due to the indirect aerosol effect, Nature, 427, 231-234, 2004.

Pope, C. A., Burnett, R. T., Thun, M. J., Calle, E. E., Krewski, D., Ito, K., Thurston, G. D.: Lung cancer, cardiopulmonary mortality, and long-term exposure to fine particulate air pollution, J. Am. Med. Assoc., 287(9), 1132-1141, 2002.

Pósfai, M., Anderson, J. R., and Buseck, P. R.: Soot and sulfate aerosol particles in the remote marine troposphere, J. Geophys. Res., 104, 21 685-21 693, 1999.

Pósfai, M., Gelencser, A., Simonics, R., Arato, K., Li, J., Hobbs, P. V., and Buseck, P. R: Atmospheric tar balls: Particles from biomass and biofuel burning, J. Geophys. Res., 109, D06213, doi:10.1029/2003JD004169, 2004.

Raga, G. B., Baumgardner, D., Kok, G., and Rosas, I.: Some aspects of boundary layer evolution in Mexico City, Atmos. Environ., 33, 5013-5021, 1999.

Ramamanthan, V., Crutzen, P. J., Lelieveld, J., Mitra, A. P., Althausen, D., Anderson, J., Andreae, M. O., Cantrell, W., Cass, G. R., Chung, C. E., Clarke, A. D., Coakley, J. A., Collins, W. D., Conant, W. C., Dulac, F., Heintzenberg, J., Heymsfield, A. J., Holben, B., Howell, S., Hudson, J., Jayaraman, A., Kiehl, J. T., Krishnamurti, T. N., Lubin, D., McFarquhar, G., Novakov, T., Ogren, J. A., Podgorny, I. A., Prather, K., Priestley, K., Prospero, J. M., Quinn, P. K., Rajeev, K., Rasch, P., Rupert, S., Sadourny, R., Satheesh, S. K., Shaw, G. E., Sheridan, P., and Valero, F. P. J.: Indian Ocean Experiment: An integrated analysis of the climate forcing and effects of the great Indo-Asian haze, J. Geophys. Res., 106, D22, 28 371-28 398, 2001.

Reddy, M. S. and Boucher, O.: A study of the global cycle of carbonaceous aerosols in the LMDZT general circulation model, J. Geophys. Res., 109, D14202, doi:10.1029/2003JD004048, 2004.

Riemer, N., Vogel, H., and Vogel, B.: Soot aging time scales in polluted regions during day and night, Atmos. Chem. Phys., 4, 1885-1893, 2004,

SRef-ID: 1680-7324/acp/2004-4-1885

Rosen, H., Novakov, T., and Bodhaine, B. A.: Soot in the Arctic, Atmos. Environ., 15, 1371-1374, 1981.

Saathoff, H., Naumann, K. H., Schnaiter, M., Schock, W., Mohler,
O., Schurath, U., Weingartner, E., Bysel, M., and Baltensperger, U.: Coating of soot and $\left(\mathrm{NH}_{4}\right)_{2} \mathrm{SO}_{4}$ particles by ozonolysis products of $\alpha$-pinene, J. Aerosol Sci., 34, 1297-1321, 2003.

Sakurai, H., Park, K., McMurry, P. H., Zarling, D. D., Kittelson, D. B., and Ziemann, P. J.: Size-dependent mixing characteristics of volatile and nonvolatile components in diesel exhaust aerosols, Environ. Sci. Technol., 34, 5487-5495, 2003.

Salcedo, D., Dzepina, K., Onasch, T. B., Canagaratna, M. R., Jayne, J. T., Worsnop, D. R., Gaffney, J., Marley, N., Johnson, K. S., Zuberi, B., Molina, L. T., Molina, M. J., and Jimenez, J. L.: Characterization of ambient aerosols in Mexico City during the MCMA-2003 campaign with Aerosol Mass Spectrometry Part II: overview of the results at the CENICA supersite and comparison to previous studies, Atmos. Chem. Phys. Discuss., 5, 4183-4221, 2005,

SRef-ID: 1680-7375/acpd/2005-5-4183.

Schnaiter, M., Horvath, H., Möhler, O, Naumann, K. H., Saathoff, H., and Schöck, O. W.: UV-VIS-NIR spectral optical properties of soot and soot-containing aerosols, J. Aerosol Sci., 34, 14211444, 2003.

Sekiguchi, M., Nakajima, T., Suzuki, K., Kawamoto, K., Higurashi, A., Rosenfeld, D., Sano, I., and Mukai, S.: A study of the direct and indirect effects of aerosols using global satellite data sets of aerosol and cloud parameters, J. Geophys. Res., 108, D22, 4699, doi:10.1029/2002JD003359, 2003.

Sellegri, K., Laj, P., Dupuy, R., Legrand, M., Preunkert, S., and Putaud, J. P.: Size-dependent scavenging efficiencies of multicomponent atmospheric aerosols in clouds, J. Geophys. Res., 108, D11, 4334, doi:10.1029/2002JD002749, 2003.

Shi, J. P. and Harrison, R. M.: Investigation of ultrafine particle formation during diesel exhaust dilution, Environ. Sci. Technol., 33, 3730-3736, 1999.

Schwoeble, A. J., Dalley, A. M., Henderson, B. C., and Casuccio, G. S.: Computer-Controlled SEM and microimaging of fine particles, J. Met., 40, 11-14, 1988.

Tobias, H. J., Beving, D. E., Ziemann, P. J., Sakurai, H., Zuk, M., McMurry, P. H., Zarling, D., Waytulonis, R., and Kittelson, D. B.: Chemical analysis of diesel engine nanoparticles using a Nano-DMA/thermal desorption particle beam mass spectrometer, Environ. Sci. Technol., 35, 2233-2243, 2001.

Vickerman, J. C. and Briggs, D. (Eds.): ToF-SIMS: Surface Analysis by Mass Spectrometry, IM Publications and Surface Spectra Ltd., 2001.

Virtanen, A. K. K., Ristimaki, J. M., Vaaraslahti, K. M., and Keskinen, J.: Effect of engine load on diesel soot particles, Environ. Sci, Technol., 38, 2551-2556, 2004.

Wentzel, M., Gorzawski, H., Naumann, K.-H., Saathoff, H., and Weinbruch, S.: Transmission electron microscopical and aerosol dynamical characterization of soot aerosols, J. Aerosol Sci., 34, 1347-1370, 2003.

Whiteman, C. D., Zhong, S., Brian, X., Fast, J. D., and Doran, J. C.: Boundary layer evolution and regional-scale diurnal circulations over the Mexico Basin and Mexican plateau, J. Geophys. Res., 105, 10081-10102.

Zuberi, B., Johnson, K. S., Aleks, G. K., Molina, L. T., Molina, M. J., and Laskin, A.: Hydrophilic properties of aged soot, Geophys. Res. Lett., 32, L01807, doi:10.1029/2004GL021496, 2005. 